\title{
Information services using a scientific approach to prevent the tendency of student physical bullying
}

\author{
Neviyarni Suhaili ${ }^{*}$, Netrawati ${ }^{2}$, Syarifuddin $^{3}$ \\ 1,2,3 Universitas Negeri Padang, Padang, Indonesia \\ *Corresponding author, email: neviyarni@konselor.org
}

\begin{abstract}
The tendency of student physical bullying must be prevented because it can negatively impact physical and psychological aspects for the perpetrator, the audience, and the victim. One way that can be done to prevent this tendency is by providing information services using a scientific approach. This study aimed to test the effectiveness of information services using a scientific approach to prevent student physical bullying tendency. This study was a quantitative research with the actual experimental design, the randomized pretest-posttest control group design. The research sample consisted of 30 students for the experimental group and 30 students for the control group. The data were analyzed by using the non-parametric statistics using the Kolmogorov Smirnov 2 independent sample analysis technique. The study results proved that information services using a scientific approach are effective in preventing the tendency of student physical bullying.
\end{abstract}

Keywords: Physical Bullying, Information Services, Scientific Approach

How to Cite: Suhaili, N., Netrawati, N., \& Syarifuddin, S. (2020). Information services using a scientific approach to prevent the tendency of student physical bullying. International Journal of Research in Counseling and Education, 4(2), 110-116. doi:http://doi.org/10.24036/00325za0002

\section{Introduction}

Ideally, students must be active in achieving the six educational focuses, namely having religiousspiritual strength, self-control, personality, intelligence, noble morals, and skills needed for themselves, society, nation, and state (Prayitno, 2018). However, in reality, some students still tend to behave maladaptive, namely, behavior that deviates from social normality, which will adversely affect individuals and social groups' welfare. Deviant or maladaptive behavior of students seen in school includes bullying, whether done physically, verbally, relational or electronically. Physical bullying is a type of bullying that is easily seen and identified. This form includes kicking, slapping, choking, biting, scratching, spitting on, destroying, and shattering the bullying victims' things (Coloroso, 2007).

Bullying at schools is a problem of concern around the world (Bradshaw, 2015). The study results showed that one in three children worldwide gets bullying (Priyatna, 2013). 67.9\% of high school students and $66.1 \%$ of junior high school students have been victims of bullying (Keliat, Tololiu, Daulima, \& Erawati, 2015). Based on the guidance and counseling documentation of SMPN 17 Padang in the 2018/2019 academic year, the number of student maladjustments that have been processed by the Guidance and Counseling teacher was illustrated. Based on the 391 cases, there were 123 cases related to bullying behavior. Specifically, there were 57 cases of verbal bullying, 19 cases of physical bullying, 21 cases of relational bullying, and 26 electronic bullying cases.

Physical bullying should not occur because it can harm the perpetrator, the audience, and especially the victim. Physical bullying can have a physical and psychological impact. The victim is physically injured due to a fight. Psychologically the victim becomes insecure, aloof, anxious, emotional, stressed and allows these effects to last for a long time and causes the victim to commit suicide (Arseneault, Bowes \& Shakoor, 2010; Prino, Longobardi , Fabris, Parada \& Settanni, 2019; Wolke, Copeland, Angold \& Costello, 2013). Besides, physical bullying can also create an unsafe and uncomfortable academic environment that can further lead to violence, antisocial behavior, and other negative behaviors (Siregar, Yusuf \& Wahyuni, 2019). 
Based on Law Number 232002 concerning Child Protection, children in and in the school environment must be protected from acts of violence committed by teachers, school administrators, or friends in the school concerned or other educational institutions. Thus, physical bullying at school needs more special attention from the counselor. The counselor can design and implement a Guidance and Counseling program by providing services with themes related to efforts to prevent physical bullying at schools. However, in reality, the efforts to prevent physical bullying by designing and implementing special programs and carrying out an extraordinary approach have not been carried out by Guidance and Counseling teachers (Yunika, Alizamar \& Sukmawati, 2013).

Guidance and Counseling services that can be provided include information services (Hariko, 2018). Information services are held to equip students with knowledge of data, facts in the field of school education, work, and personal and social development so that by learning about their environment, they are better able to organize and plan their own lives (Maharani, Neviyarni, \& Effendi, 2019; Prawingga, Yusuf, \& Neviyarni, 2019; Wahyudi, Neviyarni, \& Irianto, 2019; Winkle \& Hastuti, 2013). Information services are manifestations of the function of understanding Guidance and Counseling services. It will also support the implementation of other Guidance and Counseling functions concerning orientation materials and information with individual problems (Prayitno \& Amti, 2008).

Based on the Regulation of Permendikbud Number 1112014 concerning Guidance and Counseling in Primary and Secondary Education, information services in practice can be classified as essential services carried out through a classical format. Thus, information services in this context have in common with learning, whose implementation also requires appropriate learning methods or approaches. Information Services can be provided using various approaches, including using a scientific approach. The scientific approach is the direct approach provided in the 2013 curriculum (Bentri, 2017). This approach provides students with opportunities to explore and elaborate on the material being studied and provides opportunities for students to actualize their abilities through learning activities designed by educators (Rusman, 2015). This approach can also encourage and inspire students to think critically, analytically, and accurately to identify, understand, solve problems, and apply learning materials (Sinambela, 2017). This approach can also train students in communicating ideas, shape students' abilities to solve problems systematically, and students can obtain high learning outcomes (Daryanto, 2014).

Learning based on the scientific approach is more effective than the learning given by lecturing and question and answer approach. The study results proved that learning using the lecturing and question and answer approach, retention of information from the teacher was 10 percent after 15 minutes, and the acquisition of contextual understanding was 25 percent. In learning based on the scientific approach, information retention from teachers is more than 90 percent after two days, and the acquisition of contextual understanding is 50-70 percent (Daryanto, 2014).

Information services using a scientific approach are information services of Guidance and Counseling provided classically which in its implementation involves the steps of a scientific approach, namely observing, asking questions, gathering information, processing information and communicating, and creating (Daryanto, 2014; Rusman, 2015; Syarifuddin, Yusuf, Neviyarni \& Netrawati, 2020). Information services using a scientific approach are expected to convey information related to efforts to prevent physical bullying, which provide understanding and include cognitive, affective, and psychomotor domains. Thus, information services using a scientific approach are thought to be effective in preventing the tendency of student physical bullying.

This study aims to identify the differences between the tendency of student physical bullying provided with information services using a scientific approach and the tendency for student physical bullying. Provided with information services using lecturing and question and answer approach to conclude which approach is more effective between the two approaches to be used in information services to prevent the tendency of students physical bullying. The research method used was quantitative research with the true experimental design, the randomized pretest-posttest control group design (Yusuf, 2014). The data were analyzed by using descriptive statistical analysis and non-parametric statistics.

\section{Method}

The research method used was quantitative research with the true experimental design, randomized pretest-posttest control group design (Yusuf, 2014). This research design was used for the reason that this study used a sample with the same characteristics which was taken randomly from a homogeneous population (Sugiyono, 2015; Suryabrata, 2011). The population of this research was the students of SMPN 17 Padang. The research sample of this study were 30 students for the experimental group and 30 students for the control group taken by using proportional stratified random sampling technique. The decision to take the sample was by considering the average number of the students in each study group because this study was 
an experimental study that provides treatment in the form of classical information services. This research instrument used the grand theory of physical bullying from Coloroso (2007) with indicators of hitting, kicking, slapping, choking, biting, scratching, spitting on and destroying the things of the victims. The questionnaire used a Likert scale with alternative answers: very suitable, appropriate, unsuitable, inappropriate and very inappropriate. The validity of the instrument items was analyzed by using Product Moment analysis, so that based on the 16 statement items, 11 items were valid and 4 items were invalid. The total validity of the instrument was analyzed by using the odd even method with a value of $r$ count 0.501 . It was known that the value of $\mathrm{r}$ table $(\mathrm{N}=43)$ is 0.301 for a significant level $5 \%$ and 0.389 for a significant level $1 \%$. Thus, it can be said that the student physical bullying tendency instrument is valid with a significant level $1 \%$. The reliability of the instrument was determined by comparing the Cronbach's Alpha value of the instrument that was 0.826 with the minimum Cronbach's Alpha value 0.70. It was known that the Cronbach's Alpha value of the instrument is greater than the minimum Cronbach's Alpha value $(0.826>0.70)$. Thus, the student physical bullying tendency instrument was reliable with a very reliable level of reliability (Hair, Black, Babin, Anderson, \& Tatham, 2010). The data were analyzed by using the descriptive statistical analysis and non-parameteric statistics using the Kolmogorov Smirnov 2 independent sample analysis technique. This method is used because it can compare two free samples or compare data from different sources, namely data from the experimental group and data from the control group (Yusuf, 2014) with the aim of testing the effectiveness of information services using a scientific approach to prevent the tendency of student physical bullying.

\section{Results and Discussions}

Based on Permendikbud Number 111 Year 2014 concerning on Guidance and Counseling in primary and secondary education, Guidance and Counseling services were grouped into several components, namely (1) basic service, (2) specialization service and individual planning, (3) responsive service, and (4) system support. Basic service is the provision of assistance to all counselees through the preparation of classical or group structured experiences that are designed and implemented systematically in order to develop effective self-adjustment skills according to developmental stages and tasks. Information service is a part of basic guidance and counseling services in schools which are usually provided in a classical format with a total of 2 learning hours per week in each study group (Kemendikbud, 2016). Therefore, information services in this regard have something in common with learning (Syarifuddin et al., 2020).

Information services provided classically will be more effective if they use relevant learning models or approaches. The relevant learning approach provided in the 2013 curriculum is a scientific approach, which is a learning approach designed in such a way that students actively acquire cognitive, affective, and psychomotor through the steps of observing, formulating questions, gathering information, processing information / associating and communicating information. These steps can be continued by creating, namely applying knowledge to produce products in the form of objects, forms of presentation or writing (Daryanto, 2014; Directorate of Junior High School Development, 2016).

Generally, the learning approach in 2013 Curriculum is based on a taxonomy of educational objectives which in the last five decades has generally been widely recognized, namely learning outcomes which can be grouped into three domains, cognitive, affective and psychomotor. In Law Number 20 Year 2003 concerning on the National Education System, the taxonomy is adopted in the form of cognitive, affective and psychomotor formulations. The cognitive, affective, and psychomotor domains are hierarchies that cannot be separated from one another (Darmawan \& Sujoko, 2013; Gunawan \& Palupi, 2016). An individual will avoid the behavior of hurting others if he adheres to values, feelings, enthusiasm, interests, and attitudes that do not hurt others. These will not be owned by the individual if he does not have an understanding of which attitudes hurt and which attitudes do not hurt other individuals. Information services provided using a scientific approach are thought to be more effective than information services provided using lecturing and question and answer approach. In order to prove this hypothesis in detail, it can be found in the following analysis.

Table 1. The results of the analysis of the Kolmogorov Smirnov 2 Independent samples test on the Posttest of Student Physical Bullying Tendency in the Experimental Group with the Control Group 


\begin{tabular}{llr}
\hline & & Skor \\
\hline Most Extreme & Absolute &, 567 \\
Differences & Positive &, 567 \\
& Negative &,- 067 \\
Kolmogorov-Smirnov Z & & 2,195 \\
Asymp. Sig. (2-tailed) & &, 000 \\
\hline
\end{tabular}

Based on Table 1 above, the Asymp value is obtained. Sig. (2-tailed) for the two-sided test, the significance value 0.000 is smaller than the significance value $0.05(0.000<0.05)$. Then, $\mathrm{H} 0$ is rejected and $\mathrm{H} 1$ is accepted, so it means that there is a significant difference in the level of the tendency of student physical bullying between the experimental group which was provided with information services using a scientific approach and the control group which was provided with information services using lecturing and question and answer approach. Thus, it can be concluded that information services using a scientific approach are more effective in preventing the tendency of student physical bullying than information services provided using lecturing and question and answer approach. To see how the physical bullying tendency score changes in the 30 students from the experimental group in detail is shown in the following graph.

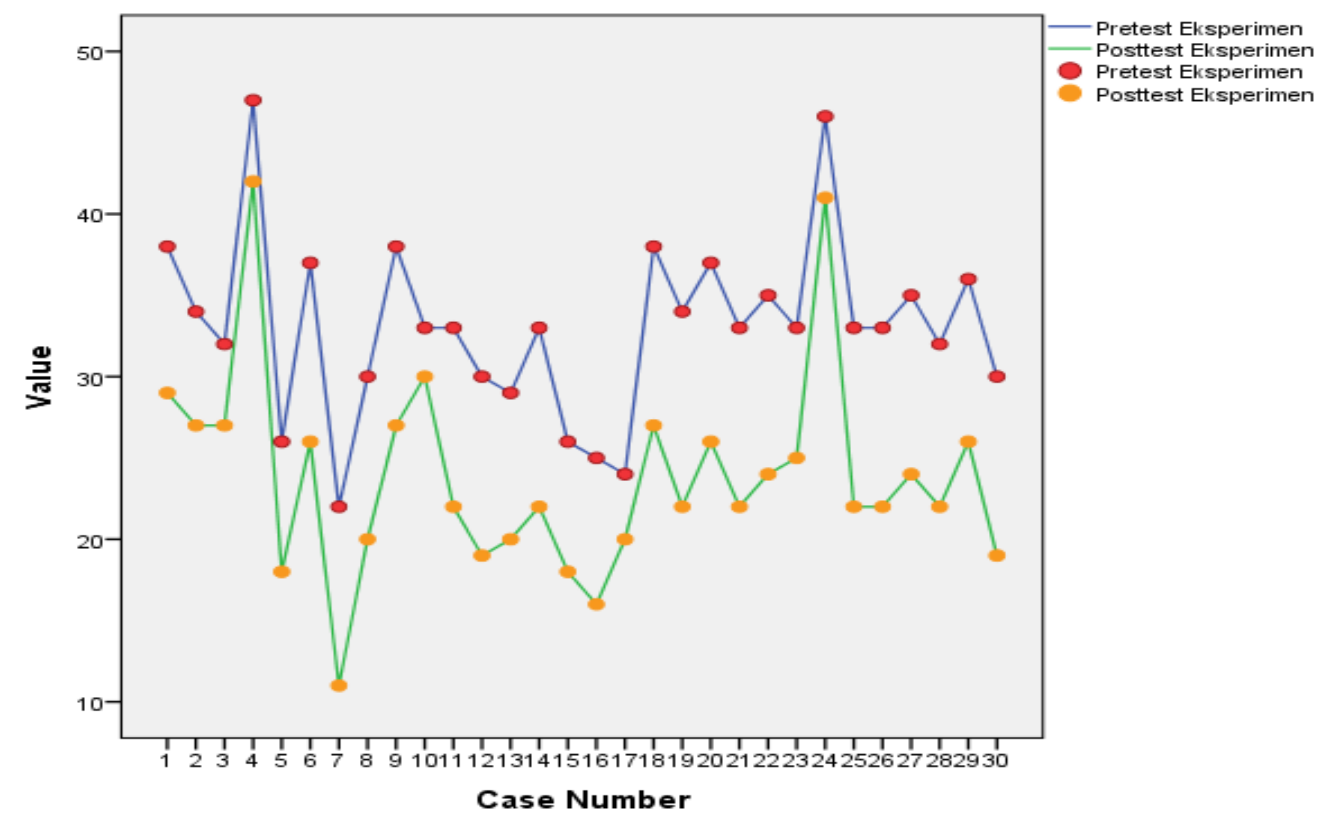

Graph 1. The Differences in the Students Physical Bullying Tendency Score of Before and After Providing Information Services Using a Scientific Approach

Based on Graph 1 above, it is illustrated that there is a decrease in the tendency score of student physical bullying before and after being given information services using a scientific approach. This shows that the information services provided using a scientific approach can prevent the tendency of student physical bullying. This conclusion does not mean that it also concludes that the information services provided by using the lecturing and question and answer approach cannot prevent student physical bullying tendency. Thus, information services provided by using the lecturing and question and answer approach can also prevent the tendency of student physical bullying. This is as illustrated in the following graph. 


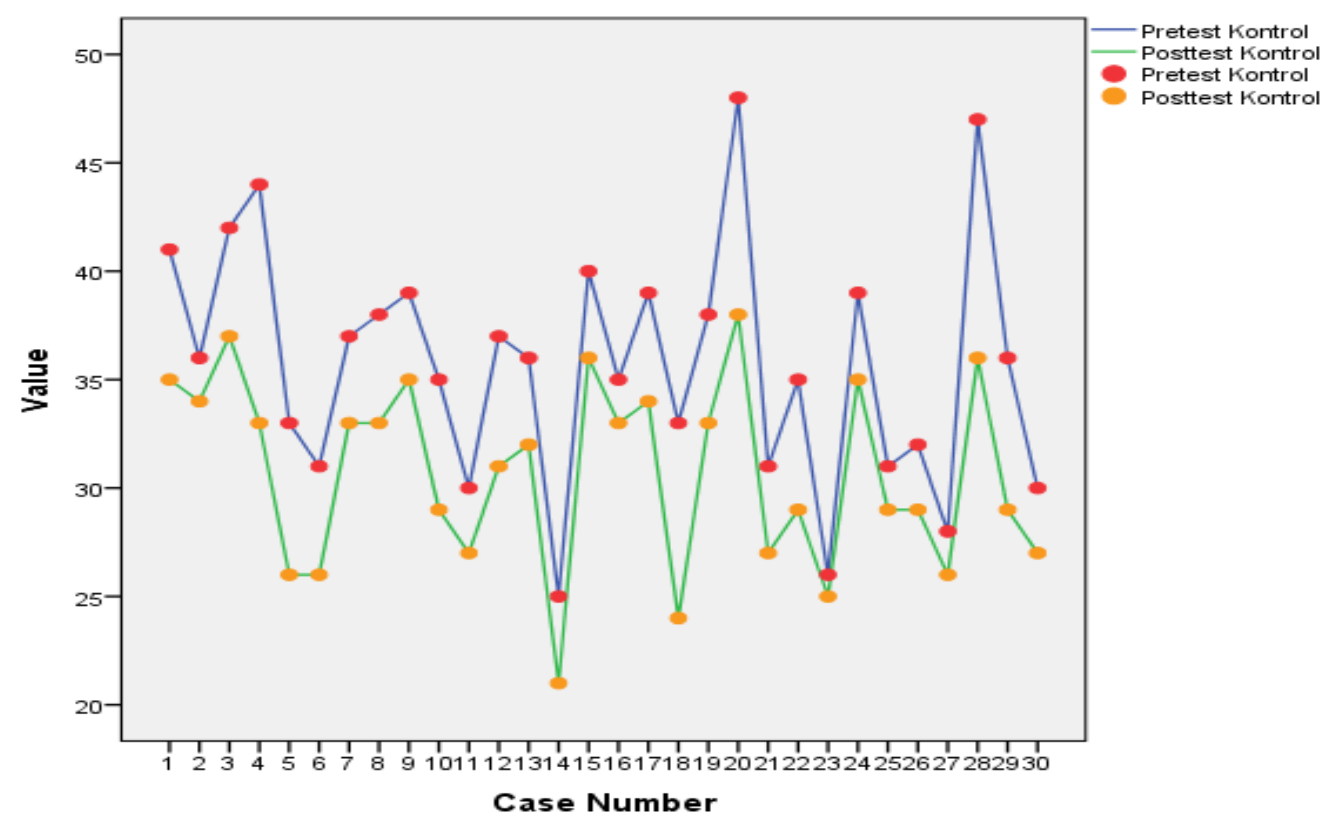

Graph 2. The Differences in Student Physical Bullying Tendency Score Before and After Providing Information Services Using the Lecturing and Question and Answer Approaches

Based on Graph 2 above, it is illustrated that there is a decrease in the student physical bullying tendency score before and after being given information services using the lecturing and question and answer approach. This concludes that the information services provided by using the lecturing and question and answer approach can also prevent the tendency of students to physically bully. However, after testing the hypothesis between the information services provided using the scientific approach with the information services provided using the lecture and question-and-answer approach as shown in Table 1, it can be concluded that the information services provided using the scientific approach are more effective than using the lecture and question and answer approach in preventing the tendency of physical bullying of students.

The results of the hypothesis test above prove the theory that the scientific approach is more effective than the lecture approach (Directorate of Junior High School Development, 2016). There are several reasons why information services provided using a scientific approach are proven to be more effective in preventing the tendency of student physical bullying than information services using lecturing and question and answer approach. First, information services using a scientific approach provide opportunities for students to explore and elaborate on the material being studied (Rusman, 2015). Information services using a scientific approach in practice require students to understand the material deeply and repeatedly at each step of observing, questioning, seeking information, processing information /associating, communicating and creating. This deep and repetitive process can enrich students 'cognition about information service material, especially material about efforts to prevent student physical bullying tendency so that students have the attitude to avoid student bullying in daily life, both as perpetrators, spectators, and as victims (Syarifuddin et al. , 2020). Second, scientific approach in practice is a student-centered learning approach. On the contrary, lecturing and question and answer approach is an educator-centered learning approach. The scientific approach requires students to be more active than $\mathrm{BK} /$ counselor teachers who only function as regulators of the information service process. On the other hand, the lecturing and question and answer approache in practice the guidance and counselor teachers dominate, so sometimes this approach makes students feel bored and uninterested in following the information service process (Syarifuddin et al., 2020). Third, according to the Regulation of the Minister of Education and Culture of the Republic of Indonesia Number 81 A Year 2013 concerning on the Implications of the General Guidelines for Learning Curriculum, each scientific step also requires several characters and competencies that must be possessed by students such as being honest, polite, obeying the rules, tolerance, respecting the opinions of others, the ability to communicate well, and develop a culture of speaking a good language. The demands in the information service process using this scientific approach will train students to have good character in everyday life which in turn also has an effect on preventing the tendency of students to physically bully (Syarifuddin et al., 2020). 
Therefore, in the future guidance and counseling teachers are suggested to prioritize the scientific approach over lectures and questions and answers in the implementation of classical format Guidance and Counseling information services, not only for topics related to efforts to prevent the tendency of student physical bullying behavior, but it is also necessary to try to apply to other topics according to the needs and problems of students. In order for the implementation of information services to be more effective with this approach, the counselors must stimulate students to actively participate in every step of the scientific approach starting from observing, asking questions, looking for information, processing information/associating, communicating to creating. In addition, the counselors must guide students to apply some of the characters and competencies that students must have such as honesty, polite, obeying rules, tolerance, respect for other people's opinions, the ability to communicate well and develop a culture of speaking good languages in every step of the implementation of information services using a scientific approach.

\section{Conclusions}

Based on the results of this study, it is concluded that information services using a scientific approach are effective in preventing the tendency of student physical bullying. The results showed that there was a decrease in the tendency of student physical bullying after being given information services using a scientific approach. This is because information services using a scientific approach provide opportunities for students to explore and elaborate on material that is studied in depth and repeatedly at each step of observing, formulating questions, gathering information, processing information/associating and communicating and creating. This deep and repetitive process can enrich students 'cognition about information service materials, especially materials about efforts to prevent student physical bullying tendency so that they have the attitude to avoid physical bullying in everyday life, both as perpetrators, viewers and as victims. In addition, the scientific approach is a student-centered learning approach that requires students to be more active than $\mathrm{BK} /$ counselors who only function as regulators of the information service process. The effectiveness of information services using a scientific approach is also due to the fact that at each step the scientific approach requires several characters and competencies that must be possessed by students such as honesty, polite, obeying rules, tolerance, respect for other people's opinions, the ability to communicate well, develop culture, and speak good language. The demands in the information service process using this scientific approach will train students to have good character in everyday life which in turn also has an effect on efforts to prevent student physical bullying tendency.

\section{References}

Arseneault, L., Bowes, L., \& Shakoor, S. (2010). Bullying victimization in youths and mental health problems:'Much ado about nothing'? Psychological Medicine, 40(5), 717-729.

Bentri, A. (2017). Mastery of primary school teacher pedagogy competency in curriculum 2013 implementation in Indonesia. The International Journal of Counseling and Education, 2(2), 78-84.

Coloroso, B. (2007). Stop bullying (memutus rantai kekerasan anak dari prasekolah hingga SMU). Jakarta: Ikrar Mandiri Abadi.

Darmawan, I. P. A., \& Sujoko, E. (2013). Revisi taksonomi pembelajaran Benyamin S. Bloom. Satya Widya, 29(1), 30-39.

Daryanto. (2014). Pendekatan pembelajaran saintifik kurikulum 2013. Yogyakarta: Gava Media.

Direktorat Pembinaan SMP. (2016). Panduan pembelajaran untuk sekolah menengah pertama. Jakarta: Ditpsmp Kemdikbud.

Gunawan, I., \& Palupi, A. R. (2016). Taksonomi Bloom-revisi ranah kognitif: kerangka landasan untuk pembelajaran, pengajaran, dan penilaian. Premiere Educandum: Jurnal Pendidikan Dasar Dan Pembelajaran, 2(02).

Hair, J. F., Black, W. C., Babin, B. J., Anderson, R. E., \& Tatham, R. L. (2010). Multivariate data analysis (7th ed.). New Jersey: Pearson Education Inc.

Hariko, R. (2018). Are high school students motivated to attend counseling. COUNS-EDU: The International Journal of Counseling and Education, 3(1), 14-21.

Keliat, B. A., Tololiu, T. A., Daulima, N. H. C., \& Erawati, E. (2015). Effectiveness assertive training of bullying prevention among adolescents in west java Indonesia. International Journal of Nursing, 2(1), 128-134.

Kemdikbud RI. (2016). Panduan operasional penyelenggaraan bimbingan dan konseling sekolah menengah pertama. Jakarta: Kemdikbud RI . 
Maharani, R., Neviyarni, S., \& Effendi, M. (2019). Effectiveness of layanan informasi using role-playing to reduce academic procrastination for college students. Journal of Educational and Learning Studies, 2(2).

Prawingga, D., Yusuf, A. M., \& Neviyarni, S. (2019). Information services with problem based learning method to reduce academic stress. Journal of Educational and Learning Studies, 2(2), 71-75.

Prayitno. (2018). Pola dasar keilmuan dan keprofesionalan pendidikan. Padang: UNP.

Prayitno, \& Amti, E. (2008). Dasar-dasar bimbingan dan konseling. Jakarta: Rineka Cipta.

Prino, L. E., Longobardi, C., Fabris, M. A., Parada, R. H., \& Settanni, M. (2019). Effects of bullying victimization on internalizing and externalizing symptoms: the mediating role of alexithymia. Journal of Child and Family Studies, 28(9), 2586-2593.

Rusman. (2015). Pembelajaran tematik terpadu teori, praktik dan penilaian. Jakarta: Rajawali Pers.

Sinambela, P. (2017). Kurikulum 2013 dan implementasinya dalam pembelajaran. Generasi Kampus, G(2).

Siregar, A. R., Yusuf, E. A., \& Wahyuni, P. (2019). Bullying at school and impact of empathy training. The Journal of Social Sciences Research, 5(1), 117-120.

Sugiyono. (2015). Metode penelitian kombinasi (mix methods). Bandung: Alfabeta

Suryabrata, S. (2011). Metode penelitian. Jakarta: Raja Gravindo Persada.

Syarifuddin, S., Yusuf, A. M., Neviyarni, S., \& Netrawati, N. (2020). An information service by using a scientific approach for preventing student cyberbullying. Journal of Educational and Learning Studies, 3(1), 3540.

Wahyudi, R., Neviyarni, S., \& Irianto, A. (2019). The effectiveness of information service with quantum learning models using music to improve student learning. Journal of Counseling and Educational Technology, 2(1), 12-18.

Winkle, W. S., \& Hastuti, S. (2013). Bimbingan konseling di institusi sekolah. Yogyakarta: Media Abadi.

Wolke, D., Copeland, W. E., Angold, A., \& Costello, E. J. (2013). Impact of bullying in childhood on adult health, wealth, crime, and social outcomes. Psychological Science, 24(10), 1958-1970.

Yunika, R., Alizamar, \& Sukmawati, I. (2013). Upaya guru bimbingan dan konseling dalam mencegah perilaku bullying di SMA Negeri se kota Padang. Jurnal Ilmiah Konseling, 2(September), 202-207.

Yusuf, A. M. (2014). Metodologi penelitian kuantitatif, kualitatif \& penelitan gabungan. Jakarta: Prenadamedia Group. 